\title{
The Influence of Board Structure on Corporate Information Transparency
}

\author{
Yibo $\mathrm{Bi}$ \\ Asia Australia Business College, Liaoning University, Shenyang, China \\ bieber2018@126.com
}

\begin{abstract}
This paper selects 500 A-share listed companies in Shanghai and Shenzhen from 2015 to 2019 as the research sample, takes the evaluation results of Shenzhen Stock Exchange on the compliance, timeliness, accuracy and integrity of information transparency of listed companies as the dependent variable, and the structure of the board of directors as the independent variable. Through descriptive statistics, correlation analysis and OLS regression, this paper studies the relationship between board independence, board size, board gender structure and information transparency of listed companies. The results show that: the separation of chairman and CEO, the size of the board of directors, the proportion of women in the board of directors are significantly positively correlated with the information transparency of listed companies. This is of great significance to improve the research on corporate information disclosure and promote the healthy development of the capital market.
\end{abstract}

Keywords: Board Structure; Board Size; Board Independence; Board Gender Structure; Corporate Information Transparency.

\section{Introduction}

\subsection{Research Background and Significance}

Corporate information transparency has always been a hot topic in the field of accounting research. High quality information disclosure can greatly reduce the degree of information asymmetry, which can effectively guide investors to make investment decisions, so as to improve the efficiency of the capital market. The quality of information disclosure of listed companies is of great significance to investors, regulators and listed companies. More transparent corporate information is conducive to investors to make more intelligent investment decisions, but also conducive to the construction of a more perfect internal governance mechanism of listed companies. In September 2020, Shanghai Stock Exchange issued the notice of "No.2 guidelines for the application of self regulatory rules of listed companies on science and Technology Innovation Board of Shanghai Stock Exchange voluntary information disclosure". The Comprehensive Research Institute of Shenzhen Stock Exchange issued the third volume of Research Report "Research on voluntary information disclosure of listed companies" in December 2002. Since 1993, China has adopted a series of information disclosure systems to improve the quality of information disclosure of listed companies and improve the development of China's capital market. For example, China's Management Co., Ltd. requires that the company's information disclosure should reflect the principles of openness, fairness and impartiality. It should truly, accurately, completely and timely disclose the information without false records, misleading statements or major omissions. It also requires mandatory disclosure of information such as fund prospectuses, investors, investment amount, company size, profits and dividends. It can be seen that the information transparency of Chinese companies is still a key issue of national concern.

The occurrence of a series of financial fraud cases from Tyco, falmo and other famous foreign companies to Ruifeng, Lantian, Zheng Baiwen and other famous domestic companies reflects that many companies abroad and abroad have financial fraud and low information transparency. For example, in 2020, lucky coffee falsely increased its sales performance by various means, and the sales volume in the third and fourth quarters of 2019 was exaggerated by $69 \%$ and $88 \%$, and the scale, growth rate, proportion and other indicators reflected in the financial statements did not match the 
equilibrium value. More and more financial fraud makes people question the authenticity of financial statements without lamenting whether the company's internal governance system is perfect or not. As the core of corporate governance, the board of directors plays an important role in controlling the information transparency of listed companies. Because the company's management and shareholders have different objective functions, the management may maximize the position from their own interests in practice. For example, in order to promote their positions, reward their salaries, and for the purpose of refinancing and allotment of shares, they will whitewash the disclosed information by using the information asymmetry generated by the control of management power, which will reduce the transparency of information, while the chairman will not Separation from management can effectively reduce information asymmetry. at the same time, most of the board members are male. Catayst (2007) took Fortune 500 companies as samples and found that the proportion of female members in the board is only $14.8 \%$. The proportion is $39.5 \%$ in Norway, $157 \%$ in the United States, $12.5 \%$ in the United Kingdom, $10.3 \%$ in Canada, $8.4 \%$ in Australia and $0.9 \%$ in Japan [1]. Many countries are trying to improve the situation. Lu Ying (2019) proposed that the UK should encourage enterprises to increase the proportion of female board members. They believe that gender differences help to overcome the information bias caused by the single characteristics of the population, and women's cautious work style is easier to disclose more accounting information [2]. At the same time, the size of the board of directors also affects the supervision ability of the board of directors, and then affects the authenticity of the company's information disclosure, resulting in financial fraud. This paper mainly studies the relationship between the size of the board of directors, the proportion of female members of the board of directors and the separation of chairman and CEO on the information transparency of the company, aiming to test whether the size of the board of directors, the proportion of female members of the board of directors and the separation of chairman and CEO improve the information transparency of Listed Companies in China.

This paper makes contributions in the following aspects: First, it expands the research scope of the influencing factors of accounting information transparency. Most of the existing studies study the influencing factors of accounting information transparency from the perspective of internal governance, while the study of information transparency of listed companies from the perspective of board structure only takes the independence of the board as the starting point of the board structure, and only uses the proportion of independent directors as a variable to measure the independence of the board. On the basis of reviewing the influencing factors of accounting information transparency at home and abroad, this paper studies the independence of the board of directors, the size of the board of directors and the gender structure of the board of directors. This paper uses the separation of chairman and CEO to measure and adds the gender structure as a new starting point of board structure to study the information transparency of listed companies, which expands the research scope of the impact of board structure on accounting information transparency. Second, it is helpful for listed companies to improve governance performance and information transparency. Chinese relevant regulatory agencies have always attached great importance to the guarantee and improvement of the quality of accounting information. The research on the influencing factors of accounting information transparency in this paper will help the regulatory authorities to establish a set of requirements or normative system for the board structure of Listed Companies in China, which is of great significance to improve the transparency of accounting information and the efficiency of resource allocation in the securities market, and protect the interests of investors. It is of great practical significance.

Therefore, these can be used as the construction of information disclosure system of China's listed companies and provide scientific theoretical and empirical basis for the standardization and improvement of the capital market. This is of great theoretical and practical significance to improve the research on corporate information disclosure and promote the healthy development of the capital market.

\subsection{Writing Ideas and Method Framework}

This paper starts with the theory, and then carries on the empirical research to carry on the analysis. 
Theoretically, from the perspective of board independence and information transparency, this paper starts with information asymmetry theory and agency theory to analyze CEO management's sacrificing the rights of the company and shareholders in order to obtain higher personal interests, and then puts forward hypotheses; From the perspective of board size and information transparency, this paper starts with group decision-making theory and team decision-making theory to analyze members' personality background. Based on the theory of resource dependence, this paper analyzes the relationship between the size of the number of people and the efficiency of governance, and further puts forward the hypothesis; from the perspective of gender structure and information transparency of the board of directors, this paper still starts with the team decision-making theory to analyze the preferences of different gender groups, and further links the preferences with the robustness of accounting information through the theory of behavioral economics the third hypothesis in this paper.

In the empirical aspect, this paper takes Shanghai and Shenzhen A-share listed companies from 2015 to 2019 as the research sample, and uses Stata software to analyze. Through descriptive statistical analysis of basic statistical data of various variables, single factor correlation analysis and multiple regression analysis, this paper tests the relationship between the size of the board of directors, the proportion of female members of the board of directors, the separation of chairman and CEO and the company's information transparency. Based on the modified Jones model, this paper makes a robustness test and puts forward some suggestions for the internal governance of the board of directors.

\subsection{The Innovation of This Paper}

The innovation of this paper lies in a more comprehensive board structure. In the past, the research of board structure on corporate information transparency did not take the gender ratio of the board as the direction of the board structure. In this study, we use the gender ratio of the board as one of the incisions of the board structure to study the relationship between the board structure and corporate information transparency.

\section{Literature Review}

At present, there are few researches on corporate information transparency in the existing research articles, and most of them are normative analysis, while there are few empirical studies. Since the mid-1990s, scholars at home and abroad began to conduct extensive research on the influencing factors of accounting information transparency from the perspective of normative research and empirical research, and have made rich research results. Since this paper studies the influencing factors of accounting information transparency from the perspective of board structure, it mainly combs the research on the influencing factors of accounting information transparency from three perspectives: board independence, board size and board gender structure.

\subsection{Board Independence and Information Transparency}

When the chairman of a listed company concurrently serves as CEO, the nomination and election of board members are easily affected, which is not conducive to the improvement of the independence of the board of directors, and then makes them whitewash the disclosure of information for the sake of maximizing their own interests, thus reducing the transparency of the company's information.

On the relationship between board independence and information transparency, scholars at home and abroad have done a lot of research. Cui Xuegang (2004) found that independent directors can improve the transparency of the company to a certain extent through empirical research, but this effect will be greatly weakened in the case of the integration of two positions [3]. Geng Xin (2016) believes that when the chairman and CEO are held by different people, the board of directors can avoid more control by the management. Therefore, the board of directors can better control the quality of information disclosure of listed companies, thus enhancing the transparency of information of listed 
companies [4]. Wei Haili (2006) research shows that the current imperfect corporate governance of Chinese enterprises seriously affects the realization of accounting transparency in China; improving the independence of the board of directors is expected to improve accounting transparency[5]. Xie Yongzhen (2006) found that the audit committee of listed companies including independent directors played a positive role in maintaining the quality of information disclosure, but did not play a significant role in preventing financial fraud, maintaining the standardization of related party transactions and ensuring the financial security of listed companies[6].Ma Zhong and $\mathrm{Wu} X i a n g y u$ (2007) conducted an empirical test on Chinese family holding listed companies, the results show that the higher the proportion of independent directors in the board of directors, the higher the degree of voluntary information disclosure of listed companies[7].Ahmend and duelman (2007) and Jensen (1993) believe that the separation of chairman and CEO can effectively guarantee the independence of the board of directors from the management, thus greatly improving the independence of the board of directors [8]. Fama (1980), Fama and Jensen (1983) hold that independent directors have no interest relationship with listed companies, and in order to maintain a good reputation, independent directors should be relatively independent with the listed companies they work for, so as to effectively supervise the activities of management, and the corresponding improvement of the independence of the board of directors, and then the board of directors is more willing to disclose more information for their own duties, and then improve the information transparency[9].

\subsection{Board Size and Information Transparency}

Using the data of 500 largest public companies in the United States from 1984 to 1991, Yermack draws the conclusion that the larger the size of the board of directors, the worse the performance of the company [10]. Lipton and Lorsch (1992) focused on the impact of board size on corporate performance [11]; Jensen (1983) basically agreed with the views of Lipton and Lorsch. Through his research, he found that too many directors may lead to the failure of the board governance, and it is easy to be controlled by the CEO, and encounter the "governance embarrassment" of the board [12]. Lehn, patro and Zhao (2004) studied 81 companies from 1935 to 2000, and found that the size of the board of directors is positively correlated with the size of the company, but negatively correlated with the growth opportunities [13].

Sun Yongxiang and Zhang Rong's Empirical Analysis on the relationship between Tobin's Q value and board size shows that there is a negative correlation between board size and corporate performance. The smaller the board size is, the better the corporate performance is [14]. Cui Wei and others studied 581 listed companies and found that only in state-owned holding companies, accounting information transparency has governance effect and affects the size of the board of directors, while in non-state-owned holding companies, it has no significant relationship [15].

\subsection{Board Gender and Information Transparency}

Murray (1989) investigated 84 food and oil companies in the Fortune 500, and found that enterprises with more female employees can better face competition and market changes, and perform better [16]. Shrader et al. (1997) took 200 Fortune 500 enterprises as research samples and found that the proportion of women in middle managers is positively correlated with enterprise performance. However, the relationship between the proportion of women in senior management and board of directors and corporate performance is not significant [17]. Carter et al. (2003) studied whether female board members affect corporate value. The author uses Tobin's Q to measure company value, and conducts an empirical study by collecting the data of 673 American companies. It is found that after controlling the company size, industry and other variables, the proportion of women in board members has a significant impact on company value and has a positive correlation. It is also found that the larger the company size and board size, the higher the proportion of female board members [18]. This shows that there is no consensus on the relationship between gender composition of board of directors and company related issues in foreign countries. The research on the relationship between the gender composition of the board of directors and corporate information transparency is very rare. 
There are few researches in this field in China. Wei Liqun and Wang Zhihui (2002) studied the relationship between top management characteristics and corporate performance of Listed Companies in China, and found that the average age of top management team has a positive correlation with corporate performance, and the educational and professional background of top management team has no significant impact on corporate performance [19]. Their research did not address the gender characteristics of top management teams. Zhang Huili et al. (2010) studied the impact of female executives on earnings quality of Listed Companies in China, and the results showed that there was no significant difference in earnings quality of Listed Companies in China because of the role of female executives [20].

From the perspective of domestic and foreign research, the research on the gender structure of the board of directors of Chinese listed companies mainly focuses on its impact on corporate performance, corporate value, earnings quality, financial restatement and so on, while the impact on the internal governance of the company remains to be studied, especially on the direction of corporate information transparency. This paper attempts to make up for this gap and provide a theoretical basis for improving the transparency of corporate information.

\section{Theoretical Analysis and Research Hypothesis}

\subsection{Board Independence and Information Transparency}

(1) Information Asymmetry Theory

The theory of information asymmetry refers to that in the market economic activities, all kinds of personnel have different understanding of the relevant information; Those who have sufficient information are often in a more favorable position, while those who lack information are in a more unfavorable position. Information asymmetry is usually divided into two categories. The first is external information asymmetry. This happens between listed companies and external investors. As an external investor, he is in the disadvantage of information asymmetry. Therefore, if an investor wants to know more about the company, he can only disclose limited information through the company's documents. The second is internal information asymmetry. This happens between the board and management. According to the "broker" hypothesis, professional managers have the motivation to realize their own interests at the expense of shareholders' interests, which leads to the occurrence of information asymmetry between them. This problem will become more serious when the chairman of a listed company is also the CEO. In this case, it is difficult for the board of directors to maintain its relative independence, thus it is difficult to guarantee the quality of information disclosure of listed companies and lose the ability to protect the interests of shareholders. Finally, the transparency of the company's information is also under great threat.

(2) Agency Theory

Agency relationship, that is, the separation of ownership and management power of listed companies, that is, the ownership of the chairman and the management power of the CEO are implemented by different people, with the shareholder as the principal and the CEO as the agent. In the ideal state of information symmetry, the board of directors can supervise the activities of the management. However, there is information asymmetry between listed companies, so there are many CEOs who sacrifice the rights of the company and shareholders in order to obtain higher personal interests. The goal of the board of directors of the principal is to maximize the value of the enterprise, while the management of the agent focuses on the maximization of personal interests. In listed companies, many managements will take private orders for personal interests and directly take the wealth that should belong to the company for their own. Therefore, more transparent information disclosure should be established between the board of directors and CEO, to improve the information transparency of listed companies.

Based on the above theoretical analysis, the following hypotheses are put forward 
Hypothesis 1: under other conditions, the separation of chairman and CEO will improve the information transparency of the company. That is to say, there is a positive correlation between separation and information transparency.

\subsection{Board Size and Information Transparency}

\section{(1) Group Decision Theory}

According to social psychology, the increase in the number of decision-makers requires more effort and time to reach an agreement. However, the final decision-making result will show relatively more compromise and less extreme cases, which will reduce their risk preference, because the robustness of accounting information is mainly reflected in the reduction of risk. Therefore, the larger group experience shows more moderate and steady accounting decision-making, and then reflects higher accounting information robustness of listed companies.

(2) Team decision Theory

In a team, the more the number of team members, the richer the personality characteristics, personality ratio, family background and social experience of team members. Such a group helps to overcome the information bias caused by the single characteristic group. Therefore, the decisionmaking views and suggestions of such a team will be more rational and scientific, so the more comprehensive the accounting information disclosed.

(3) Resource Dependence Theory

According to this theory, the size of the board of directors can be used as a measure of the ability of an organization to obtain key resources through the connection with the external environment, which reflects the approximate "content" of the company's contractual environment and the number of expert recommendations provided by the board services. The greater the demand for external effective connections, the larger the board should be. The increase of board members not only helps enterprises absorb more experts and talents from both inside and outside, but also helps enterprises understand the direction of policy guidance of national science and technology innovation. Therefore, the relatively large board of directors is more conducive to improving governance efficiency and improving the quality of company information.

Based on the above theoretical analysis, the following hypotheses are put forward

Hypothesis 2: under other conditions unchanged, the size of the board of directors is positively related to the transparency of information disclosure of listed companies. That is to say, the larger the size of the board of directors, the higher the transparency of information disclosure.

\subsection{Board Gender and Information Transparency}

\section{(1) Theory of Behavioral Economics}

According to behavioral economics, people are not rational when dealing with things. Women tend to be cautious, steady and conservative, while men tend to be bold and radical. When the external environment competition is very fierce, their style will be magnified, that is, women are more conservative and steady, men are more confident and bold. Therefore, when the proportion of female members increases, the prudence and conservatism of accounting information will greatly increase.

(2) Team Decision Theory

As we all know, in traditional Chinese thought, men are more suitable for career development than women, so the proportion of men in the board of directors is often much higher than that of women. Gender difference helps to overcome the information bias caused by the single characteristic group. According to the theory of team decision-making, there are cognitive bias and asymmetric information problems in individual decision-making. So, a team that integrates the opinions and suggestions of members of different genders and backgrounds will be more rational and scientific. Therefore, the team that increases the proportion of female members on the board of directors can adopt more suggestions, consider more comprehensively, and disclose more stable and complete accounting information than the team that has a much higher proportion of men than women before.

Based on the above theoretical analysis, the following hypotheses are put forward 
Hypothesis 3: under other conditions unchanged, the proportion of women in the board of directors is positively related to the transparency of information disclosure of listed companies.

\section{Research Design}

\subsection{Sample Selection and Data Sources}

This paper selects Shanghai and Shenzhen A-share listed companies from 2015 to 2019 as the research sample, and obtains a total of 1365 groups of observations. The data were collected from CSMAR, and were processed and tested with stata 15.

The samples are selected according to the following criteria: the companies with ST and ST * in the sample are excluded because they are not universal; The companies in financial industry are excluded because the accounting standards of financial industry are quite different from those of other industries, and the relevant indicators are not comparable between financial industry and nonfinancial industry; The samples with missing data are excluded because they may affect the effectiveness of the results.

\subsection{Variable Definition}

Table 1. Variable Definition

\begin{tabular}{|c|c|c|}
\hline Variable Name & Variable Symbol & Definition \\
\hline $\begin{array}{c}\text { Transparency of } \\
\text { accounting information }\end{array}$ & TRANSPARENCY & $\begin{array}{c}\text { When the evaluation result of Shenzhen stock exchange } \\
\text { information disclosure is unqualified, TR }=1, \text { qualified, TR }= \\
\text { 2, good, TR =3, excellent, TR = 4. }\end{array}$ \\
\hline $\begin{array}{c}\text { The status of the } \\
\text { positions of chairman } \\
\text { and CEO }\end{array}$ & DUAL & $\begin{array}{c}\text { Is the chairman and CEO separated from the CEO? Value 1 } \\
\text { means yes, value 0 represents no }\end{array}$ \\
\hline Board Size & BSIZE & Board size, number of shareholders \\
\hline $\begin{array}{c}\text { Gender ratio of board of } \\
\text { directors }\end{array}$ & FEMALE & $\begin{array}{c}\text { The proportion of female members of the board of directors, } \\
\text { the ratio of the number of female members in the total } \\
\text { number of members of the board of directors }\end{array}$ \\
\hline $\begin{array}{c}\text { Company Size } \\
\text { Financial Risk }\end{array}$ & ASSET & $\begin{array}{c}\text { The scale of listed companies is measured by the total assets } \\
\text { of listed companies, which is the natural logarithm of the total } \\
\text { assets }\end{array}$ \\
\hline $\begin{array}{c}\text { Operating performance } \\
\text { Proportion of } \\
\text { independent directors }\end{array}$ & TOBIN'SQ & $\begin{array}{c}\text { Capital structure, asset liability ratio, total liabilities divided } \\
\text { by total assets }\end{array}$ \\
\hline $\begin{array}{c}\text { Number of board } \\
\text { meetings }\end{array}$ & INDEP & PMEET \\
\hline $\begin{array}{c}\text { Number of general } \\
\text { meetings }\end{array}$ & SMEET & Proportion of independent directors \\
\hline $\begin{array}{c}\text { Number of board of } \\
\text { supervisors }\end{array}$ & BMEET & Number of board meetings \\
\hline $\begin{array}{c}\text { Shareholding ratio of } \\
\text { the largest shareholder }\end{array}$ & FIRST & $\begin{array}{c}\text { Shareholding ratio of the largest shareholder, number of } \\
\text { shares held by the largest shareholder / total number of shares }\end{array}$ \\
\hline $\begin{array}{c}\text { Cash ratio } \\
\text { Year }\end{array}$ & CASH & Yash ratio, (Monetary Fund + securities) / current liabilities \\
\hline Industry & INDUSTRY & Annual dummy variable \\
\hline
\end{tabular}

(1) Explained Variable

Since 2001, Shenzhen Stock Exchange has been evaluating the information transparency of listed companies. Shenzhen Stock Exchange comprehensively evaluates the information disclosure of listed companies from four aspects: compliance, timeliness, accuracy and integrity of daily information disclosure of listed companies, and comprehensive reward and punishment of listed companies, and 
finally forms the evaluation results, which are divided into four types: unqualified, qualified, good and excellent. In this paper, information transparency is regarded as the explanatory variable of the study, and it is recorded as "TR". When the evaluation result of Shenzhen stock exchange information disclosure is unqualified, $\mathrm{TR}=1$, qualified, $\mathrm{TR}=2$, good, $\mathrm{TR}=3$, excellent, $\mathrm{TR}=4$.

(2) Explanatory Variable

According to the previous theoretical analysis and research hypotheses, choose whether the chairman of the board concurrently serves as CEO (DUAL), board size (BSIZE) and gender ratio (FEMALE) as explanatory variables.

(3) Control Variable

The main control variables used in this paper are company size (ASSET), financial risk (LEV), operating performance (TOBINSQ), proportion of independent directors (INDEP), number of board meetings (DMEET), number of shareholders' meetings (SMEET), number of board of supervisors (BMEET), shareholding ratio of the largest shareholder (FIRST) and cash ratio (CASH). At the same time, this paper also considers the influence of year and industry, and adds year and industry to control the influence of different industries in different years.

\subsection{Model Building}

According to the previous theoretical analysis and research hypotheses, the following three regression models are constructed to test the research hypotheses.

Board Independence and Information Transparency

$$
\begin{aligned}
& \text { Transparency }{ }_{i, t}=\alpha_{0}+\alpha_{1} \text { Dual }_{i, t-1}+\alpha_{2} \text { Asset }_{i, t-1}+\alpha_{3} \text { Lev }_{i, t-1}+\alpha_{4} \text { Tobin' } Q_{i, t-1} \\
& +\alpha_{5} \text { Indep }_{i, t-1}+\alpha_{6} \text { Dmeet }_{i, t-1}+\alpha_{7} \text { Smeet }_{i, t-1}+\alpha_{8} \text { Bmeet }_{\mathrm{i}, t-1}+\alpha_{9} \text { First }_{i, t-1}+ \\
& \alpha_{10} \text { Cash }+\beta \text { Year }+\lambda \text { Industry }+\varepsilon_{i, t}
\end{aligned}
$$

Board Size and Information Transparency

$$
\begin{aligned}
& \text { Transparency }{ }_{i, t}=\alpha_{0}+\alpha_{1} \text { Bsize }_{i, t-1}+\alpha_{2} \text { Asset }_{i, t-1}+\alpha_{3} \text { Lev }_{i, t-1}+\alpha_{4} \text { Tobin' } Q_{i, t-1} \\
& +\alpha_{5} \text { Indep }_{i, t-1}+\alpha_{6} \text { Dmeet }_{i, t-1}+\alpha_{7} \text { Smeet }_{i, t-1}+\alpha_{8} \text { Bmeet }_{i, t-1}+\alpha_{9} \text { First }_{i, t-1}+ \\
& \alpha_{10} \text { Cash }+\beta \text { Year }+\lambda \text { Industry }+\varepsilon_{i, t}
\end{aligned}
$$

Board Gender and Information Transparency

$$
\begin{aligned}
& \text { Transparency } \\
& +\alpha_{i, t}=\alpha_{0}+\alpha_{1} \text { Female }_{i, t-1}+\alpha_{2} \text { Asset }_{i, t-1}+\alpha_{3} \text { Lev }_{i, t-1}+\alpha_{4} \text { Tobin's }_{i, t-1} \\
& +\alpha_{5} \text { Indep }_{i, t-1}+\alpha_{6} \text { Dmeet }_{i, t-1}+\alpha_{7} \text { Smeet }_{i, t-1}+\alpha_{8} \text { Bmeet }_{\mathrm{i}, t-1}+\alpha_{9} \text { First }_{i, t-1}+ \\
& \alpha_{10} \text { Cash }+\beta \text { Year }+\lambda \text { Industry }+\varepsilon_{i, t}
\end{aligned}
$$

\section{Empirical Analysis}

\subsection{Descriptive Statistics}

The descriptive statistical results of each variable in the model are shown in Table 2. The average value of transparency is 3.04, which indicates that the average level of Listed Companies in China has reached a good level. Secondly, the $1 / 4$ quantile of transparency is 3 , which indicates that more than $75 \%$ of listed companies' information disclosure is level B from 2015 to 2019 , indicating that the overall information transparency of Listed Companies in China is good. The average value of dual is 0.351 , which indicates that more than $50 \%$ of the company's chairman and CEO are in a state of separation. Thus, the separation of chairman and CEO is helpful to improve the company's 
information transparency to a certain extent. On the average, the size of the board of directors is close to 8, which is in line with Jensen's (1993) optimal size of the board of directors (7-8) [21], In this case, the high efficiency of the board of directors is conducive to the improvement of performance and information transparency. The average proportion of female members on the board of directors is only $17 \%$, which is relatively low.

In terms of control variables, the minimum proportion of independent directors is $33.3 \%$, which indicates that China's listed companies have met the requirements of the guiding opinions on the establishment of independent director system in listed companies (ZJF [2001] No. 102), which stipulates that the board members of listed companies should include at least one third of the independent directors. On average, the average value of the assets of the sample is (e21.865), the maximum value is (e25.715) yuan, and the minimum amount is (e19.508), indicating that there is a large difference between the size of each company. Tobinsq has an average of 2.72 and a standard deviation of 2.33, which indicates that the profitability of each company has a very large volatility. The average value of the asset liability ratio is $40.4 \%$, which is in a moderate and appropriate state. The average share holding ratio of the first largest shareholder is $32.7 \%$, indicating that most companies in China are still in the "one share only big" situation.

Table 2. Descriptive Statistics

\begin{tabular}{|c|c|c|c|c|c|c|c|c|}
\hline Variable & $\mathrm{N}$ & Mean & $\mathrm{SD}$ & Min & P25 & P50 & P75 & $\max$ \\
\hline Transparency & 1365 & 3.024 & 0.683 & 1.000 & 3.000 & 3.000 & 3.000 & 4.000 \\
\hline Dual & 1365 & 0.351 & 0.477 & 0.000 & 0.000 & 0.000 & 1.000 & 1.000 \\
\hline Bsize & 1365 & 8.279 & 1.499 & 5.000 & 7.000 & 9.000 & 9.000 & 12.000 \\
\hline Female & 1365 & 0.170 & 0.142 & 0.000 & 0.077 & 0.143 & 0.250 & 0.615 \\
\hline Indep & 1365 & 0.383 & 0.058 & 0.333 & 0.333 & 0.364 & 0.429 & 0.600 \\
\hline Asset & 1365 & 21.865 & 1.311 & 19.508 & 20.878 & 21.686 & 22.615 & 25.715 \\
\hline Tobinsq & 1365 & 2.720 & 2.330 & 0.168 & 1.089 & 1.955 & 3.616 & 12.137 \\
\hline Lev & 1365 & 0.404 & 0.208 & 0.054 & 0.235 & 0.384 & 0.558 & 0.876 \\
\hline Smeet & 1365 & 4.010 & 2.177 & 1.000 & 3.000 & 4.000 & 5.000 & 13.000 \\
\hline Dmeet & 1365 & 11.095 & 4.728 & 4.000 & 8.000 & 10.000 & 13.000 & 31.000 \\
\hline First & 1365 & 32.702 & 13.493 & 8.790 & 22.350 & 30.760 & 41.620 & 72.630 \\
\hline Bmeet & 1365 & 7.195 & 2.724 & 2.000 & 5.000 & 7.000 & 9.000 & 16.000 \\
\hline Cash & 1365 & 0.819 & 1.224 & 0.031 & 0.209 & 0.407 & 0.879 & 7.816 \\
\hline
\end{tabular}

\subsection{Correlation Analysis}

In this paper, Spearman correlation coefficient is used for correlation analysis, because Spearman uses the rank of two sides of the quantity to analyze, this method has no strict requirements on variables, because the transparency is not strictly continuous, so Spearman correlation coefficient is the most appropriate choice for analysis.

According to the correlation result 5-2, we find that transparency of listed companies is significantly positively correlated with the size of the board of directors and the proportion of female members on the board of directors at the level of $1 \%$, which preliminarily supports hypothesis 2 and hypothesis 3. Transparency of listed companies is significantly negatively correlated with the separation of chairman and CEO at the level of $1 \%$, which preliminarily supports hypothesis 1 . In the control variables, transparency is negatively correlated with dmeet, smeet and LEV, and positively correlated with asset, tobinsq, cash ratio and first. Correlation analysis is only the result of univariate analysis, more accurate detection will be reflected in multiple linear regression.

\subsection{Multiple Regression Analysis}

Table 3 describes the OLS regression results of the model that the separation of chairman and CEO, the size of the board of directors and the proportion of female members of the board of directors affect the company's information transparency as the dependent variable. 
Through the first column, we can see that the regression coefficient of the separation of chairman and CEO for the company's information transparency is -0.183 , and it is significantly negatively correlated at the level of $1 \%$, which indicates that when the separation of chairman and CEO of a company, the board of directors has higher independence, which is more conducive to its more effective supervision and management of CEO and its management, and thus improve the efficiency of listed companies Therefore, it supports hypothesis 1 of this paper.

Table 3. Correlation Analysis

\begin{tabular}{|c|c|c|c|c|c|c|c|c|c|c|c|c|c|}
\hline Variable & Transparency & Dual & Bsize & Female & Indep & Asset & Tobinsq & Lev & Smeet & Dmeet & Bmeet & Cash & First \\
\hline Transparency & 1.000 & & & & & & & & & & & & \\
\hline Dual & $\begin{array}{c}-0.138 \\
* * * *\end{array}$ & 1.000 & & & & & & & & & & & \\
\hline Bsize & $\begin{array}{c}0.145 \\
* * *\end{array}$ & 0.279 & 1.000 & & & & & & & & & & \\
\hline Female & ${ }_{* * *}^{0.145}$ & 0.034 & $\begin{array}{l}0.080 \\
* * *\end{array}$ & 1.000 & & & & & & & & & \\
\hline Indep & -0.014 & $\begin{array}{c}0.133 \\
* * *\end{array}$ & $\begin{array}{c}0.536 \\
* * *\end{array}$ & 0.026 & 1.000 & & & & & & & & \\
\hline Asset & ${ }_{* * *}^{0.089}$ & 0.196 & $\begin{array}{c}0.305 \\
* * *\end{array}$ & 0.013 & $\begin{array}{c}- \\
0.035\end{array}$ & 1.000 & & & & & & & \\
\hline Tobinsq & $\begin{array}{c}0.060 \\
* *\end{array}$ & $\begin{array}{c}0.168 \\
* * *\end{array}$ & $0 . \overline{-203}$ & $\begin{array}{c}0.046 \\
*\end{array}$ & 0.024 & 0.583 & 1.000 & & & & & & \\
\hline Lev & $\begin{array}{c}-0.130 \\
* * * *\end{array}$ & 0.137 & $\begin{array}{c}0.221 \\
* * *\end{array}$ & $\begin{array}{c}-0.050 \\
*\end{array}$ & $\begin{array}{c}- \\
0.031\end{array}$ & $\begin{array}{c}0.625 \\
* * *\end{array}$ & $\begin{array}{c}-0.524 \\
* * *\end{array}$ & 1.000 & & & & & \\
\hline Smeet & $\begin{array}{c}-0.135 \\
* * * *\end{array}$ & 0.002 & 0.019 & -0.034 & 0.007 & $\begin{array}{c}0.276 \\
* * *\end{array}$ & $\begin{array}{c}-0.143 \\
* * * *\end{array}$ & $\begin{array}{c}0.355 \\
* * *\end{array}$ & 1.000 & & & & \\
\hline Dmeet & $\begin{array}{c}-0.098 \\
* * * *\end{array}$ & $\overline{0.009}$ & 0.028 & 0.012 & 0.025 & $\begin{array}{c}0.346 \\
* * *\end{array}$ & $\begin{array}{c}-0.167 \\
* * *\end{array}$ & $\begin{array}{c}0.351 \\
* * *\end{array}$ & $\begin{array}{c}0.627 \\
* * *\end{array}$ & 1.000 & & & \\
\hline Bmeet & -0.028 & $\begin{array}{c}0.057 \\
* *\end{array}$ & 0.103 & 0.006 & $\begin{array}{c}0.078 \\
* * *\end{array}$ & 0.027 & -0.026 & $\begin{array}{c}0.054 \\
* *\end{array}$ & $\begin{array}{c}0.480 \\
* * *\end{array}$ & $\begin{array}{c}0.525 \\
* * * *\end{array}$ & 1.000 & & \\
\hline Cash & $\underset{* * *}{0.116}$ & $\begin{array}{c}0.074 \\
* * *\end{array}$ & $\begin{array}{c}- \\
0.127 \\
* * *\end{array}$ & $\begin{array}{c}0.101 \\
* * *\end{array}$ & 0.006 & $\begin{array}{c}0 . \\
0.305 \\
* * *\end{array}$ & $\begin{array}{c}0.421 \\
* * *\end{array}$ & $\begin{array}{c}0.539 \\
0 . * *\end{array}$ & $\begin{array}{c}- \\
0.169 \\
* * *\end{array}$ & $\begin{array}{c}-0.202 \\
* * * *\end{array}$ & $\begin{array}{c}-0.108 \\
* * *\end{array}$ & 1.000 & \\
\hline First & $\begin{array}{c}0.164 \\
* * *\end{array}$ & $\begin{array}{c}0.046 \\
*\end{array}$ & $\begin{array}{c}-\overline{0} 19 \\
0.019\end{array}$ & $\begin{array}{c}0.115 \\
* * * *\end{array}$ & $\overline{0.006}$ & $\overline{0.000}$ & 0.033 & 0.011 & ${ }_{* * *}^{0.112}$ & $\begin{array}{c}-0.099 \\
* * * *\end{array}$ & $\begin{array}{c}-0.109 \\
* * * *\end{array}$ & 0.013 & 1.000 \\
\hline
\end{tabular}

Through the model test regression results in the second column, we can see that the correlation regression coefficient of board size for corporate information transparency is 0.082 and it is significantly positive correlation at the level of $1 \%$. It shows that when the board size of a company increases, the mutual supervision and management responsibilities within the board will become stronger, and then improve the quality of corporate accounting information. Therefore, this result provides evidence for hypothesis 2 .

Through the third column, we can see that the regression coefficient of the proportion of female board members to the company's information transparency is significantly positive at the level of 5\%, and the correlation regression coefficient is -0.183 , which indicates that compared with the companies with the overwhelming proportion of male board members in the traditional culture, increasing the proportion of female board members will make women cautious, steady and cautious, and this style will be integrated into the company's governance, thus making the company more competitive. The accounting information is more robust and accurate, which supports the third hypothesis of this paper. 
As for the control variables, in the three models, the regression coefficients of asset and first are significantly positively correlated at the level of $1 \%$, which indicates that the larger the scale of a company, the higher the shareholding ratio of the first shareholder, and the better the information transparency of the company. Tobinsq's regression coefficient has a significant positive correlation at the level of $5 \%$, indicating that the better a company's profit is, the higher its information transparency is. The regression coefficient of Smeet and Bmeet is significantly positive correlation at the level of about $10 \%$, which indicates that the more times a company's shareholders' meeting and board of supervisors' meeting are, the higher the company's information transparency is. The regression coefficient of Lev is negatively correlated at the level of $1 \%$, which indicates that the higher the asset liability ratio is, the worse the information transparency is.

Table 4. OLS Regression Analysis

\begin{tabular}{|c|c|c|c|}
\hline \multicolumn{4}{|c|}{ TRANSPARENCY } \\
\hline & (1) & (2) & (3) \\
\hline Dual & $-0.183 * * *$ & & \\
\hline & $(-3.49)$ & & \\
\hline Bsize & & $0.082 * * *$ & \\
\hline & & $(3.54)$ & \\
\hline Female & & & $0.456^{* *}$ \\
\hline & & & $(2.37)$ \\
\hline Indep & 0.108 & $1.064 * *$ & -0.076 \\
\hline & $(0.26)$ & $(1.99)$ & $(-0.19)$ \\
\hline Asset & $0.173 * * *$ & $0.159 * * *$ & $0.178 * * *$ \\
\hline & $(6.43)$ & $(5.63)$ & $(6.78)$ \\
\hline Tobinsq & $0.035^{* *}$ & $0.033 * *$ & $0.030^{* *}$ \\
\hline & $(2.33)$ & $(2.18)$ & $(2.03)$ \\
\hline Lev & $-0.798 * * *$ & $-0.827 * * *$ & $-0.784 * * *$ \\
\hline & $(-4.22)$ & $(-4.36)$ & $(-4.13)$ \\
\hline Smeet & $-0.027 *$ & $-0.026^{*}$ & $-0.026^{*}$ \\
\hline & $(-1.93)$ & $(-1.81)$ & $(-1.87)$ \\
\hline Dmeet & -0.009 & -0.009 & -0.010 \\
\hline & $(-1.17)$ & $(-1.26)$ & $(-1.39)$ \\
\hline Bmeet & $0.020^{*}$ & $0.021 * *$ & $0.019^{*}$ \\
\hline & $(1.96)$ & $(2.09)$ & $(1.83)$ \\
\hline First & $0.007 * * *$ & $0.007 * * *$ & $0.006^{* * *}$ \\
\hline & $(3.83)$ & $(3.92)$ & $(3.33)$ \\
\hline Cash & -0.004 & -0.000 & -0.006 \\
\hline & $(-0.19)$ & $(-0.02)$ & $(-0.30)$ \\
\hline cons & -0.642 & $-1.427 * *$ & -0.681 \\
\hline & $(-1.09)$ & $(-2.37)$ & $(-1.18)$ \\
\hline $\mathrm{N}$ & 1365 & 1365 & 1365 \\
\hline $\operatorname{adj} . R^{2}$ & 0.187 & 0.191 & 0.180 \\
\hline
\end{tabular}

\subsection{Robustness Analysis}

In this section, we will use the modified Jones model to test the empirical results by using the maneuverability accrual profit instead of the transparency of company information as a dependent variable to strengthen the empirical results. The modified Jones model is regressed by year and industry to get the operating accrued profit Disacc, which can be used to represent the company's earnings progress. Because the positive and negative sign of the operating accrued profit represents the direction of earnings, this paper uses the absolute value of disacc to reflect the information transparency of the company. The greater the absolute value of disacc, the lower the transparency of company information. 


$$
\frac{\mathrm{TA}_{i, t}}{A T A_{i, t}}=\beta_{0} \frac{1}{A T A_{i, t}}+\beta_{1} \frac{\Delta R E V_{i, t}-\Delta R E C_{i, t}}{A T A_{i, t}}+\beta_{2} \frac{P P E_{i, t}}{A T A_{i, t}}+\varepsilon_{i, t}
$$

Table 5. Robustness Analysis

\begin{tabular}{|c|c|c|c|}
\hline & \multicolumn{3}{|c|}{ DISACC } \\
\hline & $\mathrm{b} / \mathrm{t}$ & $\mathrm{b} / \mathrm{t}$ & $\mathrm{b} / \mathrm{t}$ \\
\hline Dual & $0.010^{* *}$ & & \\
\hline Bsize & $(2.56)$ & $-0.002^{*}$ & \\
\hline & & $(-1.90)$ & -0.001 \\
\hline Female & & & $(-0.11)$ \\
\hline & & & -0.018 \\
\hline Indep & -0.026 & -0.052 & $(-0.62)$ \\
\hline & $(-0.89)$ & $(-1.51)$ & $-0.008^{* * *}$ \\
\hline Asset & $-0.007^{* * *}$ & $-0.007^{* * *}$ & $(-4.92)$ \\
\hline & $(-4.48)$ & $(-4.22)$ & $0.004^{* * *}$ \\
\hline Tobinsq & $0.004^{* * *}$ & $0.004^{* * *}$ & $0.067^{* * *}$ \\
\hline & $(2.90)$ & $(2.86)$ & $(4.55)$ \\
\hline Lev & $0.068^{* * *}$ & $0.068^{* * *}$ & 0.002 \\
\hline Smeet & $(4.63)$ & $(4.59)$ & $(1.64)$ \\
\hline Dmeet & 0.002 & 0.002 & 0.001 \\
\hline Bmeet & $(1.62)$ & $(1.59)$ & $(1.19)$ \\
\hline First & 0.001 & 0.001 & 0.000 \\
\hline Cash & $(1.07)$ & $(1.18)$ & $(0.35)$ \\
\hline cons & 0.000 & 0.000 & $-0.000^{*}$ \\
\hline $\mathrm{N}$ & $(0.35)$ & $(0.27)$ & $(-1.76)$ \\
\hline adj. ${ }^{2}$ & $-0.000^{*}$ & $-0.000^{*}$ & -0.001 \\
\hline & $(-1.96)$ & $(-1.95)$ & $(-0.55)$ \\
\hline & -0.001 & -0.002 & $0.189^{* * *}$ \\
\hline & $(-0.55)$ & $(-0.59)$ & 2783 \\
\hline & $0.180^{* * *}$ & $0.208^{* * *}$ & 0.106 \\
\hline
\end{tabular}

The empirical results shown in Table 3 are consistent with the empirical results of this paper, but the significance has been reduced. The reasons are as follows: the transparency used in this paper is the evaluation of the information transparency compliance, timeliness, accuracy and integrity of Listed Companies in Shenzhen Stock Exchange, and the results are relatively comprehensive and authoritative. However, the maneuverability of the modified Jones model only reflects the transparency of listed companies' information from the conservatism of accounting information, so there is a bias in significance.

\section{Conclusion}

In China's listed companies, information transparency is mostly in a good level, but the quality of information disclosure still needs to be improved, to provide a more transparent market environment for investors. Based on information asymmetry theory, behavioral economics theory and team decision-making theory, this paper uses 500 A-share listed companies in Shanghai and Shenzhen from 2015 to 2019 as research samples to test the relationship between board structure and corporate information transparency through multiple linear regression analysis, and draws the following conclusions and policy recommendations:

The separation of the chairman and CEO will improve the transparency of the company's information. When the board of directors and management are not elected for the same person, the 
management will not be controlled by the board members. According to the data, the number of internal directors in China is very low, and the proportion of internal directors is even negatively related to the transparency of company information in the single variable correlation analysis. Eng mak (2003) thinks that the proportion of independent directors is negatively related to the voluntary disclosure of listed companies, because of the listed companies in China The management or major shareholders of the company have the right to hire and pay independent directors, which leads to the lack of independence of independent directors, furthermore, the supervision ability of the board of directors to listed companies is weakened, which increases the occurrence of fraud, thus the objectivity and reliability of accounting information cannot be guaranteed, and the transparency of company information is reduced. Therefore, China's listed companies should avoid the combination of chairman and CEO to improve the transparency of accounting information.

The size of the board of directors is positively related to the transparency of information disclosed by listed companies. When the board members of a company are less than one hour, the mutual supervision among board members will weaken. Therefore, the listed companies in China should increase the board size to improve the transparency of information.

The proportion of women in the board of directors is positively related to the information transparency of listed companies. When most of the board members of a company are male, the internal governance of the company will be overconfident and careless, and then take extreme risktaking decisions, and make the information deviation of a single group more serious, thus reducing the information transparency. Therefore, increasing the proportion of female members of the board of directors will overcome the information bias of a single group to a certain extent, and adopt more careful and detailed suggestions, to improve the quality of accounting information.

Therefore, on the one hand, this paper expands the research scope of the influencing factors of accounting information transparency, makes up for the gap from the gender structure of the board of directors as the incision of the board structure to study accounting information transparency, enriches the relevant theory and research, on the other hand, this paper also reflects that through the separation of chairman and CEO, increasing the size of the board of directors, and improving the female member ratio of the board of directors To improve the transparency of accounting information. This provides methods and feasible suggestions for listed companies to improve governance performance, improve corporate information transparency and protect the interests of investors. At the same time, this paper also has limitations and shortcomings.

First, it is too limited to study corporate information transparency only from the separation of chairman and CEO and the proportion of women in board members. Due to the differences between different individuals, the family background and personality analysis of the specific members of the board of directors should also be considered, but such data disclosure is not comprehensive enough and lack of relevant data.

Finally, this paper studies the transparency of corporate information only for listed companies, and many other non-public companies have not been studied. If non-public companies want to be listed, they must strictly control the financial system and corporate budget system, achieve norms, standards, and transparency of accounting information and internal system. Therefore, it is still of great significance to study the information disclosure of non-public companies for their listing, but such data are rarely disclosed by the government and lack of authenticity of internal disclosure data. Therefore, it is hoped that these limitations and deficiencies can be solved in further research.

\section{References}

[1] Catalyst, 2007, Catalyst Census of Women Board Directors of the Fortune 1000, New York: Catalyst.

[2] Lu Ying. Research on the influence mechanism of female directors on corporate social responsibility [D]. Northwest University, 2019.

[3] Cui Xuegang. The influence of corporate governance mechanism on corporate transparency [J]. Accounting research, 2004 (8): 72-80. 
[4] Geng Xin. Research on independence of board of directors and information transparency of Listed Companies [D]. China University of Petroleum (East), 2016.

[5] Wei Haili. Accounting transparency and corporate governance structure [J]. Business accounting, 2006 (05): 12-14.

[6] Xie Yongzhen. An Empirical Study on the governance efficiency of Audit Committee of Chinese Listed Companies [J]. Nankai management theory, $2006(01): 66-73+83$.

[7] Ma Zhong, Wu Xiangzi. The influence of pyramid structure on voluntary information disclosure: empirical verification from family holding listed companies [J]. Accounting research, 2007 (1): 44-50.

[8] Ahmed, A.S., and Duellman, S, 2007. Accounting conservatism and board of director characteristics: An empirical analysis. Journal of accounting and economics, 43(2), pp.411-437.

[9] Fama, E.F., and Jensen, M.C. ,1983. Separation of ownership and control. Journal of law and economics, pp.301-325.

[10] Yermack. Higher Market Valuation of Companies with a Small Board of Directors. Journal of Financial Economics, 1996, (40):185-211.

[11] Lipton M.J., Lorch, 1992, “A Modest Proposal for Improving Corporate Governance”, Business Lawyer 4:59-77.

[12] Fama, E.F., and Jensen, M.C. ,1983. Separation of ownership and control. Journal of law and economics, pp.301-32.

[13] Lehn, K., S. Patro and M. Zhao,2004, 'Determinants of the Size and Structure of Corporate Boards: 1935 2000', University of Pittsburgh Working Paper.

[14] Sun Yongxiang, Zhang Rong. Board size, corporate governance and performance [J]. Enterprise economics, 2000 (10): 13-15.

[15] Cui Wei, Lu Zhengfei. Board size, independence and accounting information transparency: Empirical Evidence from China's capital market [J]. Nankai management review, 2008 (02): 22-27.

[16] Murray, A.,1989, “Top Management Group Heterogeneity and Firm Performance” Strategic Management Journal, 10, pp. 125-142.

[17] Shrader, C. B., V. Blackburn \& P. Iles, 1997, 'Women in Management and Firm Financial Value: An Exploratory Study', Journal of Managerial Issues, 9 (3), pp. 355-372.

[18] Carter, D., B. Simkins \& W. Simpson, 2003, Corporate Governance, Board Diversity, and Firm Value, Financial Review, 38, pp.33-53.

[19] Wei Liqun and Wang Zhihui, 2002, an empirical study on the relationship between the characteristics of executives and corporate performance of Listed Companies in China, Nankai management review, No.4.

[20] Zhang Huili, Zhang Ran, Lin Jingyi. Does female executives affect earnings quality? Based on large sample analysis of Listed Companies in China [J]. Financial theory and practice, 2010,31 (06): 62-66.

[21] Jensen, M. C. The Modern Industrial Revolution, Exit, and the Failure of Internal Control Systems[J]. Journal of Finance, 1993, 48(3).

[22] Eng L L, Mak Y T. Corporate Governance and Voluntary Disclosure[J]. Journal of Accounting and Public Policy, 2003, 22(4): 325-345. 